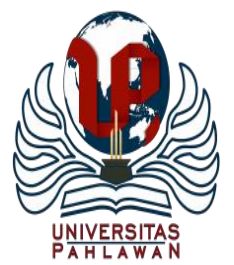

Edukatif : Jurnal Ilmu Pendidikan Volume 3 Nomor 5 Tahun 2021 Halm 2371 - 2379

EDUKATIF: JURNAL ILMU PENDIDIKAN

Research \& Learning in Education

https://edukatif.org/index.php/edukatif/index

\title{
Penerapan Media Podcast terhadap Menyimak Puisi dalam Pembelajaran Daring Siswa
}

\author{
Yulistiani Eka Putri ${ }^{1 凶}$, Wienike Dinar Pratiwi ${ }^{2}$, Een Nurhasanah ${ }^{3}$
}

Universitas Singaperbangsa Karawang, Indonesia ${ }^{1,2,3}$

E-mail : yulistiani57@gmail.com ${ }^{1}$, wienike.dinar@ fkip.unsika.ac.id ${ }^{2}$, een.nurhasanah@ staff.unsika.ac.id ${ }^{3}$

\begin{abstract}
Abstrak
Penelitian ini di latarbelakangi oleh pembelajaran jarak jauh karena Covid-19 dan turunnya hasil keterampilan menyimak puisi karena bahan simakan hanya sebatas guru yang membacakannya. Sehingga tujuan dalam penelitian ini untuk mengetahui adakah peningkatan dalam penerapan media podcast terhadap menyimak puisi dalam pembelajaran daring. Pendekatan penelitian menggunakan kuantitatif dengan desain eksperimen pretestposttest control group design. Sampel yang digunakan adalah 60 siswa kelas X SMK Rosma Karawang. Hasil penelitian yang diperoleh dari pretest-posttest menunjukkan data normal dan homogen. Pengujian hipotesis pretest kelas kontrol dan eksperimen menghasilkan nilai signifikansi $0,002<0,05$. Posttest kelas kontrol dan eksperimen menghasilkan nilai signifikansi $0,000<0,05$. Nilai rata-rata kelas eksperimen lebih besar dari kelas kontrol, hal ini karena kelas eksperimen mendapat perlakuan media podcast. Dapat disimpulkan bahwa adanya peningkatan terhadap keterampilan menyimak puisi dengan penerapan media podcast dalam pembelajaran daring dan hasil kuesioner siswa kelas eksperimen menunjukkan media podcast menarik dan memudahkan siswa mengerjakan soal tes.
\end{abstract}

Kata Kunci: Media podcast, menyimak puisi, pembelajaran daring.

\begin{abstract}
This research was motivated by distance learning due to Covid-19 and the decline in poetry listening skills because the listening material was only limited to the teacher reading it. So the purpose of this study is to find out whether there is an increase in the application of podcast media to listening to poetry in online learning. The research approach uses a quantitative experimental design with pretest-posttest control group design. The sample used was 60 students of class X SMK Rosma Karawang. The results obtained from the pretest-posttest showed normal and homogeneous data. Testing the pretest hypotheses for the control and experimental classes resulted in a significance value of $0.002<0.05$. The control and experimental class posttest resulted in a significance value of $0.000<0.05$. The average value of the experimental class is greater than the control class, this is because the experimental class is treated with podcast media. It can be concluded that there is an increase in poetry listening skills by the application of podcast media in online learning and the results of the experimental class student questionnaire show that podcast media is interesting and makes it easier for students to work on test questions.
\end{abstract}

Keywords: Podcast media, listening to poetry, online learning

Copyright (c) 2021 Yulistiani Eka Putri, Wienike Dinar Pratiwi, Een Nurhasanah

$\triangle$ Corresponding author:

Email : yulistiani57@gmail.com

DOI : https://doi.org/10.31004/edukatif.v3i5.858

ISSN 2656-8063 (Media Cetak)

ISSN 2656-8071 (Media Online)

Edukatif : Jurnal Ilmu Pendidikan Vol 3 No 5 Tahun 2021 p-ISSN 2656-8063 e-ISSN 2656-8071 
2372 Penerapan Media Podcast terhadap Menyimak Puisi dalam Pembelajaran Daring Siswa - Yulistiani Eka Putri, Wienike Dinar Pratiwi, Een Nurhasanah

DOI: https://doi.org/10.31004/edukatif.v3i5.858

\section{PENDAHULUAN}

Saat ini dunia sedang dihadapi oleh Coronavirus Diseases 2019 (Covid-19) yaitu penyakit yang disebabkan oleh coronavirus sindrom pernapasan akut berat 2 (SARS-CoV-2). Presiden Joko Widodo mengeluarkan Peraturan Pemerintah (PP) No 21 tahun 2020 tentang Pembatasan Sosial Berskala Besar (PSBB). PP ini dibuat untuk Percepatan Penanganan Corona Virus Disease 2019 (Covid-19) pada 31 Maret 2020. Hal itu pula mengakibatkan sekolah tidak diperbolehkan untuk pembelajaran tatap muka. Menurut SE Nomor 4 Tahun 2020 tentang Pelaksanaan Kebijakan Pendidikan dalam Masa Darurat Penyebaran Coronavirus Diseases 2019 (Covid-19) yaitu kegiatan belajar mengajar dilakukan di rumah secara daring atau jarak jauh (Coppola \& Maloney, 2009).

Dengan adanya peraturan pemerintah yang mengharuskan kegiatan belajar mengajar dilakukan di rumah membuat pendidik dituntut untuk berinovasi dan paham dengan teknologi agar pembelajaran tetap terlaksana. Di tengah wabah pandemi Covid-19 yang melanda dunia khususnya Indonesia saat ini, sistem pembelajaran dihadapkan dengan situasi yang menuntut guru untuk meningkatkan penguasaaan media digital dalam pembelajaran jarak jauh (Susilowati et al., 2020). Pembelajaran jarak jauh dapat disebut juga pembelajaran daring. Daring merupakan akronim dari Dalam Jaringan. Daring adalah suatu kegiatan yang dilaksanakan melalui perangkat elektronik komputer yang membutuhkan akses internet. Menurut Isman (2016: 587) pembelajaran daring merupakan suatu proses pembelajaran yang memanfaatkan jaringan internet saat pelaksanaannya. Sedangkan Harjanto dan Sumunar (dalam Jamaludin dkk, 2020: 3) menyatakan bahwa pembelajaran daring merupakan proses transformasi pendidikan konvensional ke dalam bentuk digital sehingga memiliki tantangan dan peluang tersendiri. Guru harus menyiapkan strategi pembelajaran yang sesuai seperti media, metode, dan sumber belajar yang akan digunakan. Metode dan media pembelajaran adalah aspek penting dalam proses belajar mengajar (Susilowati et al., 2020). Bantuan metode atau media pembelajaran tidak hanya sesuai melainkan yang menarik minat siswa dalam belajar, terutama dalam pembelajaran daring agar siswa tidak bosan.

Salah satu mata pelajaran yang memerlukan strategi pembelajaran yang sesuai dalam pembelajaran jarak jauh adalah mata pelajaran bahasa dan sastra Indonesia. Pada mata pelajaran bahasa dan sastra Indonesia memiliki empat keterampilan berbahasa yang harus dikuasai siswa, yaitu keterampilan menyimak, keterampilan berbicara, keterampilan membaca, dan keterampilan menulis. Terutama dalam keterampilan menyimak, seseorang dapat dikatakan berhasil dalam menyimak jika ia dapat menyampaikan ulang informasi secara tepat dari simakan secara lisan atau tertulis. Keterampilan menyimak merupakan salah satu keterampilan berbahasa yang fundamental dan penting serta harus dikuasai oleh peserta didik (Henry Guntur Tarigan, 2008). Hal ini sejalan dengan pendapat Iskandarwassid \& Sunendar (2016) dalam buku (Rahman et al., n.d.) yang memaparkan bahwa menyimak sangatlah penting dalam kehidupan manusia, karena melalui kegiatan menyimak, kita dapat mengetahui beberapa informasi yang diperlukan dalam kehidupan sehari-hari.

Berdasarkan observasi yang telah dilakukan di SMK Rosma Karawang, hasil belajar yang diperoleh dari keterampilan menyimak puisi menurun karena siswa kesulitan menuangkan hasil simakannya, guru menyadari bahwa siswa kurang antusias dan tidak menyimak dengan baik. Hal ini disebabkan karena keterampilan menyimak puisi dengan cara siswa membaca teks puisi yang diperintahkan guru. Kegiatan pembelajaran menyimak terkadang masih dilakukan sebatas guru membacakan bahan simakan dari buku atau peserta didik yang membacakan bahan simakan untuk teman-temannya (Abidin, 2012). Jika hal ini terus menerus dilakukan, dan tidak adanya inovasi dalam pembelajaran maka hasil belajar siswa tidak meningkat dan siswa tidak dapat melatih keterampilan menyimaknya. Keterampilan menyimak memiliki peran penting dan mempunyai kedudukan yang lebih besar jika dibandingkan dengan keterampilan bahasa lainnya (Azizah \& Nugraheni, 2020). 
2373 Penerapan Media Podcast terhadap Menyimak Puisi dalam Pembelajaran Daring Siswa - Yulistiani Eka Putri, Wienike Dinar Pratiwi, Een Nurhasanah

DOI: https://doi.org/10.31004/edukatif.v3i5.858

Puisi adalah ungkapan imajinatif yang dirangkai dengan irama dan memperlihatkan pemaknaan (Sembodo, 2010). Sedangkan menurut (Wahyuni dan Risti, 2014) puisi adalah salah satu bentuk karya sastra yang dibentuk dengan kata-kata indah dan mengandung makna yang dalam. Dalam puisi terdapat unsur pembangun puisi yaitu struktur fisik dan struktur batin puisi. Menurut (Waluyo, 2010) mengungkapkan bahwa puisi terdiri atas dua struktur yaitu struktur fisik dan struktur batin. Struktur fisik terdiri atas diksi, pengimajian, kata konkret, bahasa figuratif, verifikasi dan tipografi, sedangkan struktur batin puisi meliputi tema, perasaan, nada, dan suasana, serta amanat atau pesan yang terkandung dalam puisi.

Sesuai dengan fenomena yang telah dikemukakan di atas, maka peneliti berusaha menerapakan media podcast terhadap keterampilan menyimak puisi dalam pembelajaran daring siswa. Tujuan dari penelitian ini untuk mengetahui adakah peningkatan hasil keterampilan menyimak puisi dengan penerapan media podcast dalam pembelajaran daring siswa. Podcast merupakan akronim dari iPod Broadcasting. Dalam padanan bahasa Indonesia, kata podcast berarti siniar. Siniar dalam Kamus Besar Bahasa Indonesia (KBBI) merupakan Telekom siaran (berita, musik, dan sebagainya) yang dibuat dalam format digital (baik audio maupun video) yang diunduh melalui internet. Dengan bantuan media podcast diharapkan siswa akan antusias dan menyimak puisi dengan baik, siswa yang menyimak puisi dengan baik pasti dapat menuangkan hasil simakannya dalam tugas yang diberikan.

Peneliti menggunakan media podcast karena dapat didengarkan tanpa unduh aplikasi, siswa akan dibagikan tautan podcast nya dan dapat mendengarkan tanpa unduh. Media podcast dapat membantu siswa memahami bahan simakan, dan dalam penggunaannya yang mudah dan hemat biaya internet. Hal ini juga didukung oleh teori Abbie Brown, dkk (2007) dalam jurnal (Zellatifanny, 2020) podcast adalah file audio atau video yang diunggah di web agar dapat diakses oleh individu baik berlangganan maupun tidak dan dapat didengarkan atau ditonton dengan menggunakan komputer atau pemutar media digital portable. Podcast merupakan salah satu media pembelajaran yang efektif berbasis suara (Saksono \& Faiza, 2014). Podcast mampu meningkatkan kemampuan belajar pada siswa, dapat digunakan sebagai motivasi dan inspirasi dalam pembelajaran (Mayangsari \& Tiara, 2019). Selain itu, puisi yang diperdengarkan lewat podcast dapat membuat siswa lebih imajinatif karena dengan podcast yang hanya menampilkan audio maka siswa dapat membangun imajinasinya pada puisi yang diperdengarkan.

Dengan media podcast dapat membantu siswa dalam menyimak dan meningkatkan hasil belajar siswa. Hal ini diperkuat dengan penelitian sebelumnya mengenai media podcast. Penelitian yang dilakukan oleh Rizmi Nur Andari (2020) dalam skripsi berjudul "Peningkatan Kemampuan Berbicara dengan Model Quantum Learning Berbantuan Media Podcast Siswa Kelas XI SMKN 1 Cimahi”. Penelitian menyatakan bahwa quantum learning berbantuan media podcast telah efektif dalam upaya peningkatan kemampuan berbicara siswa kelas XI RPL A SMKN 1 Cimahi (Rizmi Nur Andari, 2020). Hal ini dibuktikan dengan meningkatnya nilai siswa yaitu 29 siswa mendapat nilai di atas KKM dan 3 siswa mendapat nilai mencapai KKM, dari nilai sebelum perlakuan yaitu terdapat 19 siswa yang nilainya di bawah KKM, 4 orang mendapat nilai mencapai KKM, 9 orang mendapat nilai di atas KKM. Selanjutnya penelitian oleh Dewi Mayangsari, Dinda Rizki Tiara (2019) dengan judul penelitian "Podcast sebagai Media Pembelajaran di Era Milenial". Podcast dalam penelitian menunjukkan efektivitas, hal ini dibuktikan dengan angket minat belajar dan hasil pre-post nilai mata kuliah diantaranya bahwa minat masuk kategori cukup yaitu dari 45,04 menjadi 44,80, sedangkan nilai mata kuliah mengalami peningkatan dari 59,4 dengan kategori sedang menjadi 68,60 termasuk kategori baik. Media podcast dianggap efektif untuk meningkatkan hasil belajar (Mayangsari \& Tiara, 2019). Selain itu penelitian oleh Adhitya Rol Asmi (2019) dengan judul penelitian "Pengembangan Media Pembelajaran Audio Berbasis Podcast pada Materi Sejarah Lokal di Sumatera Selatan". Hasil penelitian menunjukan media audio berbasis podcast pada materi sejarah Indonesia kuno 1 telah berhasil diterapkan dan memiliki nilai kevalidan dan memiliki dampak efektifitas (Asmi, 2019). Pada penelitian sebelumnya, media podcast belum digunakan dalam keterampilan menyimak puisi dan saat pembelajaran 
2374 Penerapan Media Podcast terhadap Menyimak Puisi dalam Pembelajaran Daring Siswa - Yulistiani Eka Putri, Wienike Dinar Pratiwi, Een Nurhasanah

DOI: https://doi.org/10.31004/edukatif.v3i5.858

daring. Oleh karena itu, peneliti akan melakukan penelitian dengan judul "Penerapan Media Podcast terhadap Keterampilan Menyimak Puisi (Siniar) dalam Pembelajaran Daring Siswa”. Penelitian ini dilakukan untuk mengetahui adakah peningkatan pada penerapan media podcast (siniar) terhadap keterampilan menyimak puisi dalam pembelajaran daring.

\section{METODE PENELITIAN}

Penelitian ini menggunakan pendekatan kuantitatif. Disebut kuantitatif karena data penelitian berupa angka-angka dan analisis menggunakan statistik (Sugiyono, 2016). Pada penelitian kuantitatif terdapat perlakuan (treatment) untuk mencari pengaruh perlakuan tertentu terhadap suatu objek dengan desain eksperimen. Metode yang digunakan dalam penelitian ini yaitu metode eksperimen. Eksperimen yaitu suatu cara untuk mencari hubungan sebab akibat (hubungan kausal) antara dua faktor yang sengaja ditimbulkan oleh peneliti dengan mengelimininasi atau mengurangi atau menyisihkan faktor-faktor lain yang mengganggu (Arikunto, 2010).

Penelitian ini menggunakan desain eksperimen Pretest-Posttest Control Group Design. Dalam desain ini terdapat dua kelompok yang dipilih secara acak, kemudian diberikan pretest untuk mengetahui keadaan awal pada kelompok kontrol dan kelompok eksperimen. Perbedaan dari dua kelompok ini yaitu kelompok kontrol tidak diberikan perlakuan sedangkan kelompok eksperimen diberikan perlakuan dengan media podcast. Setelah diberikan materi, kelompok kontrol dan kelompok eksperimen diberikan posttest untuk mengetahui hasil akhir adakah perbedaan yang signifikan antara kelompok kontrol dan kelompok eksperimen.

Populasi merupakan daerah generalisasi yang terdiri atas obyek atau subyek yang memiliki kualitas dan karakteristik tertentu yang ditetapkan oleh peneliti untuk dipelajari, lalu ditarik kesimpulannya (Sugiyono, 2016). Populasi dalam penelitian ini yaitu seluruh siswa kelas X SMK Rosma Karawang dengan jumlah 344 siswa yang terbagi dalam sebelas kelas.

Sampel adalah bagian dari jumlah dan karakteristik yang dimiliki oleh populasi tersebut (Sugiyono, 2016). Pengambilan sampel dengan teknik simple random sampling. Simple random sampling pengambilan anggota sampel dari populasi dilakukan secara acak tanpa memperhatikan strata yang ada dalam populasi itu, cara demikian dilakukan bila anggota populasi dianggap homogen (Sugiyono, 2016). Peneliti akan mengambil dua kelas sebagai sampel pada penelitian ini yaitu kelas X TKJ 2 sebagai kelas kontrol dengan 30 siswa, dan kelas X TKJ 3 sebagai kelas eksperimen dengan 30 siswa. Maka jumlah sampel penelitian adalah 60 siswa.

Teknik pengumpulan data menggunakan observasi, tes, kuesioner, dan dokumentasi. Adapun instrumen penelitian menggunakan tes yaitu pretest dan posttest, dan non-tes yaitu kuesioner. Pretest diberikan kepada dua kelas yang menjadi sampel penelitian dengan tujuan untuk mengetahui sejauh mana siswa mengenal dan memahami materi pelajaran yang akan diajarkan. Kemudian posttest pun diberikan kepada dua kelas tersebut untuk mengetahui apakah materi yang diberikan, telah dikuasai atau dimengerti dengan baik oleh siswa. Terdapat perbedaan dalam pembelajaran dan pemberian posttest, yakni kelas kontrol tidak mendapatkan perlakuan dengan media podcast, sedangkan kelas eksperimen mendapatkan perlakuan dengan media podcast. Kuesioner hanya diberikan kepada kelas eksperimen yang mendapat perlakuan dengan media podcast karena ingin mengetahui tanggapan siswa mengenai media podcast dalam keterampilan menyimak puisi.

Untuk mengukur variabel penelitian media podcast dan menyimak puisi, peneliti membuat kisi-kisi instrumen penelitian. Pada variabel media podcast dalam kuesionernya mencakup indikator yaitu: 1) efektif dan efisien, 2) kemudahan penggunaan media, 3) ketertarikan siswa terhadap pembelajaran, 4) perasaan senang siswa dalam mengikuti pembelajaran. Adapun variabel menyimak puisi dalam pretest-posttest mencakup indikator: 1) mampu menjelaskan definisi puisi, 2) mampu menjelaskan mengenai puisi lama dan puisi baru, 3) mampu menjelaskan struktur fisik dan struktur batin puisi, 4) mampu menentukan tema puisi yang dibaca atau diperdengarkan, 5) mampu menentukan suasana puisi yang dibaca atau diperdengarkan, 6) mampu menentukan amanat puisi yang dibaca atau diperdengarkan. 
2375 Penerapan Media Podcast terhadap Menyimak Puisi dalam Pembelajaran Daring Siswa - Yulistiani Eka Putri, Wienike Dinar Pratiwi, Een Nurhasanah

DOI: https://doi.org/10.31004/edukatif.v3i5.858

Teknik analisis data yang digunakan adalah uji prasyarat analisis dengan mencari normalitas dan homogenitas, dan uji hipotesis dengan rumus Independent T-Test. Hasil data kuesioner yang telah diisi siswa pun akan dideskripsikan hasilnya berdasarkan persentase yang didapat.

\section{HASIL DAN PEMBAHASAN PENELITIAN}

Penelitian ini dilakukan untuk mengetahui adakah peningkatan pada penerapan media podcast (siniar) terhadap keterampilan menyimak puisi dalam pembelajaran daring. Data diperoleh dari hasil pretest-posttest dan kuesioner. Instrumen tes dan kuesioner sudah melewati uji validitas yang diuji oleh dosen ahli dan guru mata pelajaran bahasa Indonesia. Tes dan kuesioner diuji kelayakan dan kesesuainnya, tidak ada soal yang dibuang melainkan diperbaiki atau diubah bahasa yang digunakan di soal. Kemudian para ahli memperbolehkan instrumen tes dan kuesioner digunakan dengan perbaikan sesuai saran. Instrumen tes digunakan untuk pretest dan posttest yang terdiri dari sepuluh soal uraian.

Pada penelitian ini menggunakan dua kelas sebagai sampel penelitian, yakni kelas kontrol dan kelas eksperimen. Kelas kontrol sebagai kelas yang tidak mendapat perlakuan dengan media podcast, sedangkan kelas eksperimen sebagai kelas yang mendapat perlakuan dengan media podcast. Hasil pretest dan posttest akan diuji sesuai dengan teknik analisis data nya dan akan menjawab dari tujuan penelitian dan hipotesis. Untuk mengetahui adakah peningkatan penerapan media podcast terhadap keterampilan menyimak, hasil posttest dari dua kelas akan dibandingkan.

\section{Tabel 1}

Statistik Deskriptif

\begin{tabular}{lrrr}
\multicolumn{4}{c}{ Statistik Deskriptif } \\
\multicolumn{1}{c}{ Kelas } & $\begin{array}{c}\text { Nilai } \\
\text { Terendah }\end{array}$ & $\begin{array}{c}\text { Nilai } \\
\text { Tertinggi }\end{array}$ & Rata-rata \\
\hline Pretest Kontrol & 70 & 85 & 78,43 \\
\hline Posttest Kontrol & 73 & 94 & 84,17 \\
\hline Pretest Eksperimen & 76 & 91 & 82,30 \\
\hline Posttest Eksperimen & 79 & 97 & 88,90 \\
\hline
\end{tabular}

Berdasarkan tabel 1 di atas, diperoleh data sebanyak 30 siswa pada kelas kontrol. Kelas kontrol memiliki mean nilai pretest 78,43 dan nilai posttest 84,17 . Selanjutnya nilai pretest sebelum diberikan materi, diketahui nilai minimum 70 dan meningkat menjadi 73 pada nilai posttest. Begitupun nilai maksimum nya mengalami peningkatan signifikan yaitu dari 85 menjadi 94 pada nilai posttest. Dapat disimpulkan bahwa nilai posttest meningkat karena siswa sudah diberikan materi pembelajaran.

Kelas eksperimen diperoleh data sebanyak 30 siswa. Pada kelas eksperimen terdapat mean nilai pretest 82,30 dan nilai posttest 88,90 . Selanjutnya nilai pretest sebelum diberikan materi, diketahui nilai minimum 76 dan meningkat pada nilai posttest menjadi 79. Begitupun nilai maksimum mengalami peningkatan yaitu dari 91 menjadi 97 pada nilai posttest. Dapat disimpulkan bahwa nilai posttest meningkat karena saat diberikan materi pembelajaran dan posttest, kelas eksperimen diberikan perlakuan dengan media podcast.

Jika membandingkan hasil nilai pretest kelas kontrol dengan nilai pretest kelas eksperimen, dapat dilihat pada tabel 1 yaitu mengalami peningkatan yang signifikan. Selanjutnya perbandingan nilai posttest kelas kontrol dengan nilai posttest kelas eksperimen, juga mengalami peningkatan. Hal ini karena kelas kontrol tidak mendapat perlakuan dengan media podcast, Kemudian data diuji normalitas dan homogenitasnya, sebelum melakukan uji hipotesis. Berikut ini adalah hasil uji normalitas dan homogenitas yang diuji dengan program SPSS 24.

Tabel 2

Hasil Uji Normalitas

\begin{tabular}{lcccc}
\hline & \multirow{2}{*}{ Kelas } & \multicolumn{3}{c}{ Kolmogorov-Smirnov $^{\mathrm{a}}$} \\
\cline { 3 - 5 } & Statistic & $\mathrm{df}$ & Sig. \\
\hline Hasil & Pretest Kontrol & 0,156 & 30 & 0,061 \\
\hline
\end{tabular}


2376 Penerapan Media Podcast terhadap Menyimak Puisi dalam Pembelajaran Daring Siswa - Yulistiani Eka Putri, Wienike Dinar Pratiwi, Een Nurhasanah

DOI: https://doi.org/10.31004/edukatif.v3i5.858

\begin{tabular}{lllll}
\hline Menyimak & Posttest Kontrol & 0,138 & 30 & 0,151 \\
\cline { 2 - 5 } Puisi & Pretest Eksperimen & 0,157 & 30 & 0,056 \\
\cline { 2 - 5 } & Posttest Eksperimen & 0,143 & 30 & 0,120 \\
\hline
\end{tabular}

Berdasarkan tabel 2 di atas, pada kelas kontrol nilai pretest menghasilkan signifikansi 0,061 >0,05 yang berarti berdistribusi normal, dan nilai posttest signifikansinya $0,151>0,05$ menunjukkan data berdistribusi normal. Selanjutnya pada kelas eksperimen, nilai pretest signifikansinya 0,056>0,05 menunjukkan data berdistribusi normal, dan nilai posttest menghasilkan signifikansi $0,120>0,05$ yang berarti data berdistribusi normal. Dapat disimpulkan bahwa nilai pretest dan posttest dari kedua kelas yaitu kelas kontrol dan eksperimen menghasilkan data yang berdistribusi normal karena nilai signifikansinya lebih besar dari 0,05 . Maka dapat dilanjutkan dengan uji homogenitas dari data yang diperoleh.

Tabel 3

Hasil Uji Homogenitas

\begin{tabular}{ccccc}
\hline \multicolumn{4}{c}{ Hasil Menyimak Puisi } \\
\hline & $\begin{array}{c}\text { Levene } \\
\text { Statistic }\end{array}$ & $\mathrm{df1}$ & $\mathrm{df} 2$ & Sig. \\
\hline Pretest & 0,726 & 1 & 58 & 0,398 \\
\hline Posttest & 0,203 & 1 & 58 & 0,654 \\
\hline
\end{tabular}

Berdasarkan tabel 3 di atas terdapat hasil uji homogenitas dari nilai pretest dan posttest pada kelas kontrol dan kelas eksperimen. Diketahui nilai pretest kelas kontrol dan eksperimen memiliki signifikansi 0,398. Selanjutnya nilai posttest kelas kontrol dan eksperimen memiliki signifikansi 0,654. Maka dapat disimpulkan nilai pretest dan posttest dari kedua kelas tersebut homogen karena nilai signifikansi lebih besar dari 0,05 . Setelah data yang diperoleh dikatakan normal dan homogen, maka dapat dilanjutkan dengan uji hipotesis.

Uji hipotesis pada penelitian ini menggunakan Uji T-Test dengan rumus Independent Simple T-Test. Pengujian ini dengan bantuan program SPSS 24. Uji hipotesis dilakukan untuk menguji kebenaran suatu pernyataan secara statistik, apakah pernyataan hipotesis yang sudah dibuat dapat diterima atau ditolak. Dasar pengambilan keputusan dalam uji Independent Simple T-Test yaitu jika nilai signifikansi (2-tailed) <0,05 maka Ho ditolak dan Ha diterima, dan jika nilai signifikansi (2-tailed) >0,05 maka Ho diterima dan Ha ditolak. Adapun pernyataan hipotesis dalam penelitian yaitu: Ha terdapat peningkatan dalam penerapan media podcast (Siniar) terhadap keterampilan menyimak puisi dalam pembelajaran daring siswa kelas X di SMK Rosma Karawang, Ho Tidak terdapat peningkatan dalam penerapan media podcast (Siniar) terhadap keterampilan menyimak puisi dalam pembelajaran daring siswa kelas X di SMK Rosma Karawang. Berikut adalah hasil uji hipotesis.

Tabel 4

Hasil Uji Hipotesis

\begin{tabular}{|c|c|c|c|c|c|c|}
\hline $\begin{array}{c}\text { Hasil } \\
\text { Menyimak } \\
\text { Puisi }\end{array}$ & Kelas & Mean & $\begin{array}{c}\text { Std. } \\
\text { Deviation }\end{array}$ & Df & $\begin{array}{l}\text { Sig (2- } \\
\text { tailed) }\end{array}$ & Kesimpulan \\
\hline \multirow{2}{*}{ Pretest } & Kontrol & 78,43 & 4,125 & \multirow{2}{*}{58} & \multirow{2}{*}{0,002} & Ho Ditolak dan \\
\hline & Eksperimen & 82,30 & 5,004 & & & Ha Diterima \\
\hline \multirow{2}{*}{ Posttest } & Kontrol & 84,17 & 5,160 & \multirow{2}{*}{58} & \multirow{2}{*}{0,000} & Ho Ditolak dan \\
\hline & Eksperimen & 88,90 & 4,671 & & & Ha Diterima \\
\hline
\end{tabular}

Berdasarkan tabel 4 di atas, diketahui pretest kelas kontrol memiliki nilai mean 78,43 dan standar deviation 4,125. Sedangkan kelas eksperimen memiliki nilai mean 82,30 dan standar deviation 5,004. Nilai pretest pada dua kelas tersebut kemudian diuji dengan t-test dan menghasilkan nilai signifikansi (2-tailed) 0,002. Selanjutnya nilai posttest kelas kontrol memiliki nilai mean 84,17 dan standar deviation 5,160. Posttest 
kelas eksperimen memiliki nilai mean 88,90 dan standar deviation 4,671. Nilai posttest pada dua kelas tersebut kemudian diuji dengan t-test dan menghasilkan nilai signifikansi (2-tailed) 0,000. Jika dilihat pada dasar pengambilan keputusan, hasil uji hipotesis menghasilkan nilai signifikansi <0,05. Maka dapat disimpulkan Ho ditolak dan Ha diterima yaitu terdapat peningkatan dalam penerapan media podcast (siniar) terhadap keterampilan menyimak puisi dalam pembelajaran daring siswa kelas X di SMK Rosma Karawang.

Selanjutnya, hasil data kuesioner yang telah diisi siswa kelas eksperimen akan dideskripsikan. Untuk mengetahui tanggapan siswa mengenai penerapan media podcast terhadap pembelajaran menyimak puisi. Kuesioner terdiri dari 10 pertanyaan dengan 5 pilihan jawaban yaitu sangat setuju, setuju, ragu-ragu, tidak setuju, dan sangat tidak setuju. Berikut adalah hasil kuesioner yang telah diisi siswa kelas eksperimen.

Tabel 5

Hasil Data Kuesioner

\begin{tabular}{clllll}
\hline & \multicolumn{5}{c}{ Pilihan Jawaban } \\
\cline { 2 - 6 } No Butir Soal & $\begin{array}{c}\text { Sangat } \\
\text { Setuju }\end{array}$ & Setuju & $\begin{array}{c}\text { Ragu- } \\
\text { ragu }\end{array}$ & $\begin{array}{c}\text { Tidak } \\
\text { Setuju }\end{array}$ & $\begin{array}{c}\text { Sangat } \\
\text { Tidak } \\
\text { Setuju }\end{array}$ \\
\hline 1 & $30 \%$ & $63,3 \%$ & $6,7 \%$ & $0 \%$ & $0 \%$ \\
\hline 2 & $3,3 \%$ & $63,3 \%$ & $33,3 \%$ & $0 \%$ & $0 \%$ \\
\hline 3 & $6,7 \%$ & $70 \%$ & $23,3 \%$ & $0 \%$ & $0 \%$ \\
\hline 4 & $23,3 \%$ & $53,3 \%$ & $20 \%$ & $3,3 \%$ & $0 \%$ \\
\hline 5 & $13,3 \%$ & $60 \%$ & $23,3 \%$ & $3,3 \%$ & $0 \%$ \\
\hline 6 & $20 \%$ & $73,3 \%$ & $6,7 \%$ & $0 \%$ & $0 \%$ \\
\hline 7 & $33,3 \%$ & $56,7 \%$ & $10 \%$ & $0 \%$ & $0 \%$ \\
\hline 8 & $0 \%$ & $46,7 \%$ & $30 \%$ & $23,3 \%$ & $0 \%$ \\
\hline 9 & $3,3 \%$ & $10 \%$ & $40 \%$ & $46,7 \%$ & $0 \%$ \\
\hline 10 & $23,3 \%$ & $70 \%$ & $6,7 \%$ & $0 \%$ & $0 \%$ \\
\hline Rata-rata & $157 \%$ & $566,60 \%$ & $200,00 \%$ & $77 \%$ & $0 \%$ \\
\hline
\end{tabular}

Berdasarkan tabel 4 di atas, kuesioner yang telah diisi oleh 30 siswa atau responden menunjukkan bahwa siswa lebih banyak dan dominan memilih setuju dari tiap butir soal. Hanya soal nomor 9 pada pilihan jawaban tidak setuju mendapat persentase tinggi yaitu $46,7 \%$. Hal ini karena bentuk pernyataan negatif yaitu berisi pernyataan "Saya lebih senang jika membaca langsung teks puisi nya". Dapat disimpulkan bahwa tanggapan siswa lebih banyak yang setuju mengenai penerapan media podcast terhadap keterampilan menyimak puisi dalam pembelajaran daring.

Keterampilan menyimak puisi yang sudah dilakukan dengan penerapan media podcast menunjukkan hasil yang meningkat, yakni adanya peningkatan pada hasil posttest setelah diberikan materi pembelajaran dan perlakuan dengan media podcast. Adapun perbedaan hasil posttest pada kelas kontrol dan kelas eksperimen yang menunjukkan hasil menyimak puisi pada kelas eksperimen lebih tinggi jika dibandingkan dengan kelas kontrol. Meningkatnya hasil menyimak puisi dengan media podcast juga didukung dengan tanggapan siswa yang setuju bahwa media podcast mudah dalam penggunaannya, membantu siswa dalam mengerjakan tugas, dapat membantu siswa memahami puisi yang diperdengarkan, dan media podcast efektif digunakan saat pembelajaran daring. Dapat disimpulkan bahwa adanya peningkatan hasil menyimak puisi dengan penerapan media podcast dalam pembelajaran daring siswa.

Hasil penelitian ini sejalan dengan beberapa penelitian yang telah dilakukan. Pada penelitian (Chris Evan, 2008) hasil penelitian menunjukkan bahwa siswa meyakini podcast efektif dalam membantu mereka belajar, dibandingkan hanya membaca buku teks dan catatan. Selain itu penelitian yang dilakukan oleh Ratna Dwi yang mengemukakan hasil penelitiannya bahwa penggunaan podcast juga dapat digunakan oleh siswa 
2378 Penerapan Media Podcast terhadap Menyimak Puisi dalam Pembelajaran Daring Siswa - Yulistiani Eka Putri, Wienike Dinar Pratiwi, Een Nurhasanah

DOI: https://doi.org/10.31004/edukatif.v3i5.858

untuk memahami prinsip, ide dalam implementasi pembelajaran jarak jauh (Susilowati et al., 2020). Podcast audio dapat menjadi sumber belajar yang efektif karena: (1) sesuai dengan tujuan pembelajaran yang akan dicapai, (2) mampu menggugah imajinasi pendengar karena konten yang terdapat disajikan, selain berisi materi pembelajaran juga diperjelas dengan musik ilustrasi dan sound effect, (3) konten lebih dinamis (Saksono \& Faiza, 2014). Dengan diterapkannya media podcast dalam keterampilan menyimak puisi, siswa dapat mudah memahami puisi dibandingkan hanya membaca teks puisinya saja karena siswa dapat merasakan langsung emosi, rasa, suasana pada pembacaan puisi dari podcast.

\section{KESIMPULAN}

Berdasarkan penelitian yang dilakukan pada kelas X TKJ 2 dan X TKJ 3 di SMK Rosma Karawang, keterampilan menyimak puisi dengan media podcast menunjukkan hasil yang meningkat. Hal ini dibuktikan pada hasil posttest siswa kelas eksperimen lebih tinggi jika dibandingkan dengan kelas kontrol, dan kuesioner yang telah diisi pun menghasilkan lebih banyak jawaban setuju dengan penerapan media podcast terhadap keterampilan menyimak puisi dalam pembelajaran daring. Dapat disimpulkan bahwa media podcast berhasil diterapkan terhadap keterampilan menyimak puisi dalam pembelajaran daring karena hasil menyimak puisi meningkat. Sehingga disarankan dalam pembelajaran hendaknya pendidik berinovasi terhadap media pembelajaran yang menarik, dan dapat menerapkan media podcast pada mata pelajaran lainnya.

\section{UCAPAN TERIMA KASIH}

Puji syukur atas rahmat Allah Swt. atas karunia serta rahmatnya yang telah memberikan kelancaran dalam menyelesaikan penelitian hingga membuat artikel ini. Terima kasih diucapkan untuk kedua orang tua atas dukungan dan doa yang tiada hentinya. Terima kasih kepada dosen pembimbing Universitas Singaperbangsa Karawang, kepala sekolah SMK Rosma Karawang serta guru bahasa Indonesia dan staff, dan untuk teman-teman seperjuangan atas segala bantuan dan bimbingannya sehingga peneliti dapat menyelesaikan penelitian ini.

\section{DAFTAR PUSTAKA}

Abidin, Y. (2012). Pembelajaran Bahasa Berbasis Karakter. PT. Refika Aditama.

Arikunto, S. (2010). Prosedur Penelitian: Suatu Pendekatan Praktik. PT. Rineka Cipta.

Asmi, A. R. (2019). Pengembangan Media Pembelajaran Audio berbasis Podcast pada Materi Sejarah Lokal di Sumatera Selatan. Historia: Jurnal Pendidik Dan Peneliti Sejarah, 3(1), 49-56. https://doi.org/10.17509/historia.v3i1.21017

Azizah, A. N., \& Nugraheni, A. S. (2020). Analisis Teknik Menyimak Puisi Melalui Video Animasi Pada Siswa Kelas 2 Sd Negeri Triharjo. Jurnal Holistika, 4(2), 114-120.

Chris Evan. (2008). The Effectiveness of m-Learning in the Form of Podcast Revision Lectures in Higher Education. 50(2).

Coppola, D. P., \& Maloney, E. K. (2009). Communicating Emergency Preparedness. Communicating Emergency Preparedness, 2019(022868). https://doi.org/10.4324/9780367802820

Henry Guntur Tarigan. (2008). Menyimak Sebagai Suatu Keterampilan Berbahasa. Angkasa.

Mayangsari, D., \& Tiara, D. R. (2019). Podcast Sebagai Media Pembelajaran Di Era Milenial. Jurnal Golden Age, 3(02), 126. https://doi.org/10.29408/goldenage.v3i02.1720

Rahman, M. H. P., Rani, N., Widya, M. P., \& Rasi Yugatiati, M. P. (n.d.). Menyimak Berbicara Teori dan Praktik Teori dan Praktik.

Rizmi Nur Andari. (2020). Peningkatan Kemampuan Berbicara dengan Model Quantum Learning Berbantuan 
2379 Penerapan Media Podcast terhadap Menyimak Puisi dalam Pembelajaran Daring Siswa - Yulistiani Eka Putri, Wienike Dinar Pratiwi, Een Nurhasanah

DOI: https://doi.org/10.31004/edukatif.v3i5.858

Media Podcast Siswa Kelas XI SMKN 1 Cimahi. Repository.Upi.Edu.

Saksono, W. T., \& Faiza, I. (2014). Podcast Sebagai Sumber Belajar Berbasis Audio Audio Podcasts As Audio-Based Learning Resources. Teknodik., 18.(3), 304-314.

Sembodo, E. (2010). Contekan Pintar Sastra Indonesia Untuk SMP dan SMA. PT. Mizan Publika.

Sugiyono. (2016). Metode Penelitian Pendidikan Pendekatan Kuantitatif, Kualitatif, dan R\&D. Alfabeta.

Susilowati, R. D., Sutama, \& Faiziyah, N. (2020). Application of Podcast on Sportify as a Mathematics Learning Media in the Middle of Covid-19 Pandemic. Jurnal Riset Pendidikan Dan Inovasi Pembelajaran Matematika, 4(1), 68-78.

Wahyuni dan Risti. (2014). Kitab Lengkap Puisi, Prosa, dan Pantun Lama. SAUFA.

Waluyo, H. J. (2010). Pengkajian dan Apresiasi Pui. Widya Sari Press Salatiga.

Zellatifanny, C. M. (2020). Trends in Disseminating Audio on Demand Content through Podcast: An Opportunity and Challenge in Indonesia. Journal Pekommas, 5(2), 117.

https://doi.org/10.30818/jpkm.2020.2050202 